(C) The Authors 2014. This is an Open Access article, distributed under the terms of the Creative Commons Attribution licence (http:// creativecommons.org/licenses/by/3.0/), which permits unrestricted re-use, distribution, and reproduction in any medium, provided the original work is properly cited.

\title{
Lactose inhibits regulatory T-cell-mediated suppression of effector T-cell interferon- $\gamma$ and IL-17 production
}

\author{
Monika Paasela ${ }^{1}$, Kaija-Leena Kolho ${ }^{2}$, Outi Vaarala ${ }^{1}$ and Jarno Honkanen ${ }^{1 *}$ \\ ${ }^{1}$ Immune Response Unit, Department of Vaccination and Immune Protection, National Institute for Health and Welfare, \\ Haartmaninkatu 8, FI-O0290 Helsinki, Finland \\ ${ }^{2}$ Children's Hospital, University of Helsinki, Helsinki, Finland \\ (Submitted 19 December 2013 - Final revision received 29 May 2014 - Accepted 13 June 2014 - First published online 21 October 2014)
}

\section{Abstract}

Our interest in lactose as an immunomodulatory molecule results from studies showing that lactose binds to galectin-9, which has been shown to have various regulatory functions in the immune system including regulation of $\mathrm{T}$-cell responses. Impaired regulation of $\mathrm{T}$ helper (Th)1 and Th17 type immune responses and dysfunction of regulatory $\mathrm{T}$ cells $\left(\mathrm{T}_{\mathrm{reg}}\right)$ have been implicated in many human immunemediated diseases. In the present study, we investigated the effects of lactose on immune regulation using co-cultures of human peripheral blood mononuclear cell (PBMC)-derived $\mathrm{T}_{\text {reg }}$ and effector $\mathrm{T}$ cells $\left(\mathrm{T}_{\text {eff }}\right)$ obtained from twenty healthy adults. $\mathrm{T}_{\text {reg }}$, i.e. $\mathrm{CD} 4{ }^{+} \mathrm{CD} 25^{+} \mathrm{CD} 127^{-}$, were isolated from PBMC by immunomagnetic separation. The fraction of $\mathrm{CD} 4^{+} \mathrm{CD} 127^{-}$cells that was depleted of $\mathrm{CD} 25^{+}$cells was used as $\mathrm{T}_{\text {eff. }} \mathrm{T}_{\mathrm{reg}}$ and $\mathrm{T}_{\text {eff }}$ at a ratio 1:5 were activated and the effects of lactose on the secretion of interferon- $\gamma$ (IFN- $\gamma$ ) and IL-17 were analysed using ELISA for protein and quantitative RT-PCR for mRNA. $\mathrm{T}_{\text {reg }}$ down-regulated the secretion of both IFN- $\gamma(8 \cdot 8-3 \cdot 9 \mathrm{ng} / \mathrm{ml}, n 20, P=0 \cdot 003)$ and IL-17 $(0.83-0.64 \mathrm{ng} / \mathrm{ml}, n 15, P=0.04)$ in co-cultures, while in the presence of lactose the levels of secreted IFN- $\gamma$ and IL-17 remained high and no down-regulation was observed $(16.4 v .3 .99 \mathrm{ng} / \mathrm{ml}, n 20, P<0.0001$, and $0.74 v .0 .64 \mathrm{ng} / \mathrm{ml}, n 15, P=0.005$, respectively).

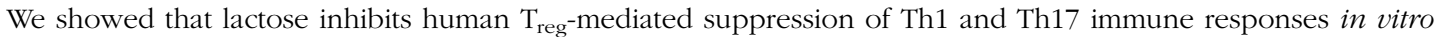

Key words: Lactose: Inflammation: Immunomodulation: $\mathbf{T}$ cells

Lactose, a $\beta$-galactoside consisting of galactose and glucose residues, is the main carbohydrate in mammalian breast milk. In the first few months of life, lactose provides energy to infants and supports the growth of lactose-fermenting commensals ${ }^{(1)}$. During development, the expression of the enzyme lactase starts to diminish and mammals become lactose intolerant, but the exact mechanisms of this developmental decline in enzyme activity are unclear ${ }^{(2,3)}$. However, in some populations, lactase expression persists due to genetic mutation, and lactose tolerance is maintained during adult life, allowing the use of lactose-containing dairy products ${ }^{(4)}$.

Galectin-9 (Gal-9) belongs to the vast group of mammalian lectins that bind to $\beta$-galactosides, such as lactose, with a conserved carbohydrate recognition domain ${ }^{(5,6)}$. Gal-9 is expressed by various cell types, such as macrophages, $\mathrm{T}$ cells and intestinal epithelial cells ${ }^{(6-9)}$. Gal-9 is widely distributed due to its importance in the host system with complex biological functions including antimicrobial immunity, cell adhesion, anti-allergic functions, regulatory $\mathrm{T}$-cell $\left(\mathrm{T}_{\text {reg }}\right)$ differentiation and effector $\mathrm{T}$-cell $\left(\mathrm{T}_{\text {eff }}\right)$ apoptosis ${ }^{(8-13)}$. Gal-9 mediates its effects by two receptors: cell-surface protein disulfide isomerase and T-cell Ig and mucin domain-3 $(\text { Tim- } 3)^{(14,15)}$. It has been demonstrated in animal models that the Gal-9/TIM-3 pathway regulates antiviral immune responses in cytotoxic $\mathrm{T}$ cells and is crucial for shutting down excessive $\mathrm{T}$ helper (Th)1 and Th17 immune responses ${ }^{(13,15,16)}$. Tim-3mediated regulation of Th1 and Th17 immune responses has been shown in human subjects by Hastings et al. ${ }^{(17)}$. In some studies, lactose has been used as a Gal-9 antagonist. Similar to Gal-9 gene silencing, lactose abrogates Gal-9-mediated immune regulation by limiting its engagement with Tim- $3^{(18)}$ This results in increased proliferation of $\mathrm{T}$ cells and induction of pro-inflammatory responses with aggravation of clinical outcomes in mouse models of experimental autoimmune encephalitis and arthritis ${ }^{(13,15,16,19)}$.

Although proper Th1 and Th17 immune responses are required for host defence in intracellular pathogen clearance and mucosal antimicrobial immunity, respectively, uncontrolled

Abbreviations: FOXP3, forkhead box P3; Gal-9, galectin-9; IFN- $\gamma$, interferon- $\gamma$; PBMC, peripheral blood mononuclear cells; $\mathrm{T}_{\text {eff }}$, effector T cells; Th, T helper;

Tim-3, T-cell Ig and mucin domain-3; $\mathrm{T}_{\text {reg, }}$, regulatory $\mathrm{T}$ cells.

* Corresponding author: J. Honkanen, fax +358 295248 599, email jarno.honkanen@thl.fi 
and excessive Th1 and Th17 immune activity may have detrimental effects and may result in the development of immunemediated diseases ${ }^{(20)}$. $\mathrm{T}_{\mathrm{reg}}$, characterised by the expression of surface antigens CD 4 and CD25 and the transcription factor forkhead box P3 (FOXP3), control inflammation by suppressing the function of $\mathrm{T}_{\text {eff. }} \mathrm{T}_{\text {reg }}$ are thought to maintain immune system homeostasis and tolerance to self-antigens and non-self-antigens ${ }^{(21-23)}$.

In the present study, we investigated the role of lactose as a potential inhibitor of human $\mathrm{T}_{\text {reg }}$-mediated immune regulation in Th1 and Th17 immune responses to evaluate the possible effects of dietary lactose on immune function in humans.

\section{Materials and methods}

\section{Isolation of human peripheral blood mononuclear cells} and enrichment of $T$ cells

Peripheral blood mononuclear cells (PBMC) were isolated from twenty healthy donors by Ficoll gradient centrifugation (FicollPaque $^{\mathrm{TM}}$ PLUS; GE Healthcare). The collected PBMC were washed three times with PBS (BioWhittaker) and resuspended in Roswell Park Memorial Institute (RPMI) 1640 culture medium (Lonza) supplemented with L-glutamine (Invitrogen), gentamicin (Sigma-Aldrich) and heat-inactivated human AB serum (Innovative Research). Before cell culture, all cell fractions were dyed with Trypan Blue for cell counting and viability assessment. $\mathrm{T}_{\text {reg }}$ from PBMC populations were enriched using the Regulatory T Cell Isolation Kit II (catalogue no. 130-094-775) according to the manufacturer's recommendation (Miltenyi Biotec). First, PBMC were labelled with a biotinylated antibody cocktail for non-CD4 and CD127 antigens and anti-biotin microbeads, and then the labelled cells were separated magnetically in an LD column (Miltenyi Biotec). Cells passing through the column comprised a pre-enriched $\mathrm{CD} 4{ }^{+} \mathrm{CD} 127^{-}$cell population, which was further enriched for $\mathrm{T}_{\text {reg }}$ by direct magnetic labelling of the surface antigen $\mathrm{CD} 25 . \mathrm{CD}^{+} \mathrm{CD} 25^{+} \mathrm{CD} 127^{-}$cells were then separated on a magnetic MS column (Miltenyi Biotec). The flow-through fraction of $\mathrm{CD}^{+}{ }^{+} \mathrm{CD} 127^{-}$Th cells that was depleted of $\mathrm{CD} 25^{+}$ $\mathrm{T}_{\text {reg }}$ was used as $\mathrm{T}_{\text {eff. }}$. Magnetic separation was performed once for each enriched cell population. The viability of enriched $\mathrm{T}_{\text {reg }}$ was $>89 \%$ and that of enriched $\mathrm{T}_{\text {eff }}$ was $>83 \%$. The purity of $\mathrm{T}_{\text {reg }}$ and $\mathrm{T}_{\text {eff }}$ was assessed by flow cytometry after magnetic separation. Typically, over $94 \%$ of gated $\mathrm{CD} 4{ }^{+} \mathrm{CD} 25^{+}$cells, representing $\mathrm{T}_{\text {reg }}$, expressed the transcription factor FOXP3 (Fig. 1(a)). The $\mathrm{CD} 4{ }^{+} \mathrm{CD} 25^{-} \mathrm{CD} 127^{-}$cell population comprising $>83 \%$ of $\mathrm{CD}^{+}$cells was used as $\mathrm{T}_{\text {eff }}{ }^{(24,25)}$. The present study was conducted according to the guidelines laid down in the Declaration of Helsinki, and all procedures involving human subjects were approved by the ethics committee of the Helsinki University Central Hospital. Written informed consent was obtained from all subjects.

\section{Cell culture}

Enriched $\mathrm{T}_{\text {eff }}$ and $\mathrm{T}_{\text {reg }}$ were cultivated in ninety-six-well plates (Thermo Scientific) in $\mathrm{CO}_{2}$ incubators at $37^{\circ} \mathrm{C}$. The culture
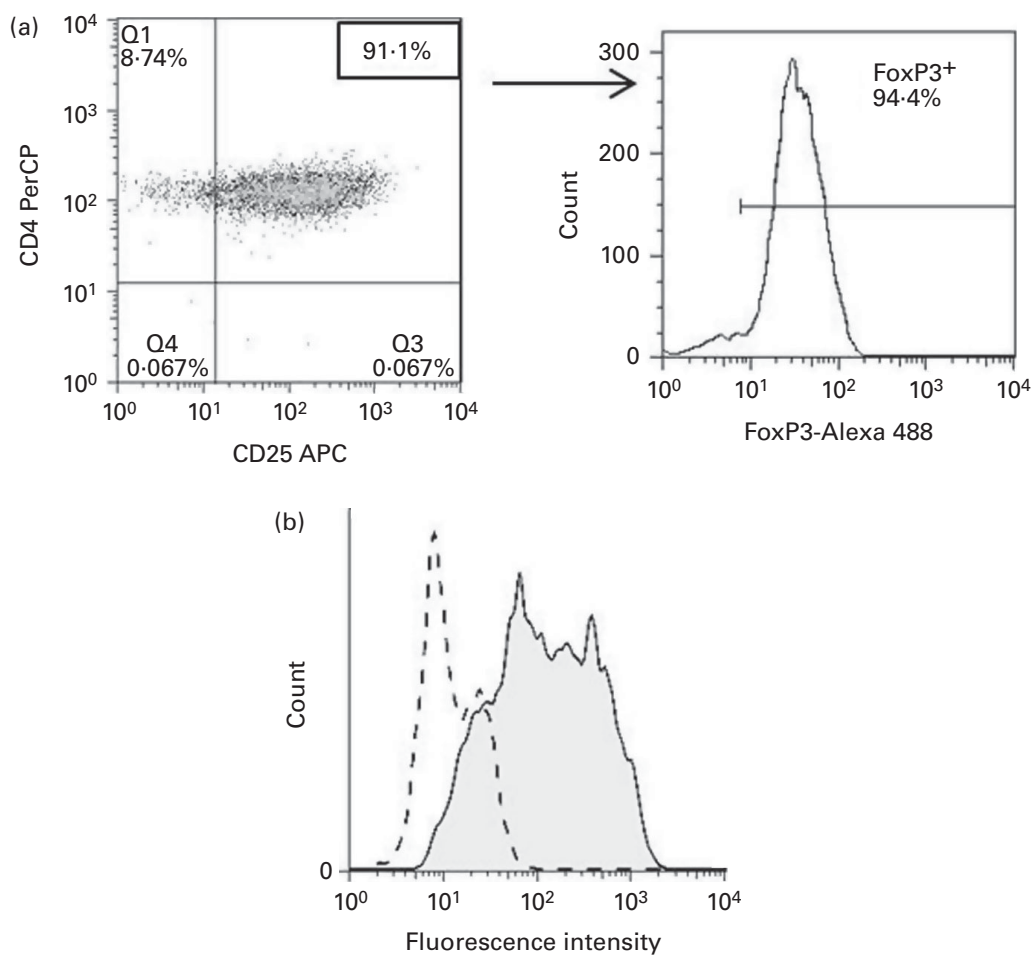

Fig. 1. Characterisation of human regulatory $T$ cells $\left(T_{r e g}\right)$ enriched from peripheral blood mononuclear cells using immunomagnetic beads. (a) A fluorescenceactivated cell sorting-based phenotype analysis of enriched $T_{\text {reg }}$ in lymphocyte gate. Typically, over $94 \%$ of gated $\mathrm{CD}^{+}{ }^{+} \mathrm{CD}_{2} 5^{+}$cells expressed the transcription factor forkhead box P3 (FOXP3), a marker for $\mathrm{T}_{\text {reg. }}$. (b) High intracellular protein expression of galectin-9 (Gal-9) in stimulated $\mathrm{T}_{\text {reg }}$ after $6 \mathrm{~d}$ of anti-CD3 and antiCD28 stimulation. ...., IgG1-phycoerythrin of stimulated $\mathrm{T}_{\text {reg; }}$ —, Gal-9-phycoerythrin of stimulated $\mathrm{T}_{\text {reg. }}$. PerCP, peridinin chlorophyll; APC, allophycocyanin. 
medium consisted of RPMI 1640 (Invitrogen) supplemented with human heat-inactivated and sterile-filtered 5\% $\mathrm{AB}$ serum, $2 \mathrm{~mm}$-L-glutamine (Invitrogen) and $25 \mu \mathrm{g} / \mathrm{ml}$ gentamicin (Sigma-Aldrich). Before experimentation, the kinetics of Gal-9 expression in stimulated $\mathrm{T}_{\text {reg }}$ obtained from two healthy individuals was studied. Enriched $\mathrm{T}_{\text {reg }}$ were stimulated with anti-CD3 and anti-CD28 for $6 \mathrm{~d}$, and the gene expression of Gal-9 was analysed at $24 \mathrm{~h}$ intervals. The peak transcription of Gal-9 occurred after $6 \mathrm{~d}$ of polyclonal stimulation of $\mathrm{T}_{\mathrm{reg}}$ (data not shown). Based on these results, $\mathrm{T}_{\text {reg }}$ were pre-stimulated for $4 \mathrm{~d}$ before the addition of lactose to the co-cultures to modulate up-regulated endogenous Gal-9 expression. The expression of Gal-9 protein was analysed by flow cytometry in stimulated $\mathrm{T}_{\text {reg }}$ after $6 \mathrm{~d}$ of stimulation.

To study the effects of lactose on the function of $\mathrm{T}_{\text {reg }}$, first $\mathrm{T}_{\text {reg }}$ and $\mathrm{T}_{\text {eff }}$ were stimulated with $5 \mu \mathrm{g} / \mathrm{ml}$ plate-bound anti-CD3 (BD Biosciences) and soluble $5 \mu \mathrm{g} / \mathrm{ml}$ anti-CD28 (BD Biosciences) in separate culture wells for $4 \mathrm{~d}$. Then, $\mathrm{T}_{\text {reg }}$ were transferred into a co-culture with $\mathrm{T}_{\text {eff }}$ at a cell ratio of 1:5 (15000 $\mathrm{T}_{\text {reg }}: 75000 \mathrm{~T}_{\text {eff }}$ in $100 \mu \mathrm{l}$ volume per well), and $30 \mathrm{~mm}$-lactose (Fluka ${ }^{\circledR}$ Analytical), $30 \mathrm{~mm}$-sucrose (Fisher Scientific) or culture medium without added sugars was added to the cultures. As controls, the $\mathrm{T}_{\text {eff }}$ were cultured alone or with only lactose. Cell-culture supernatants were collected $3 \mathrm{~d}$ after the addition of sugars and stored as such at $-70^{\circ} \mathrm{C}$, and cultured cells were collected and lysed in RLT buffer (Qiagen) and stored at $-70^{\circ} \mathrm{C}$.

\section{ELISA}

A modified ELISA was used for measuring interferon- $\gamma$ (IFN- $\gamma$ ) secretion in cell-culture supernatants. Enhanced binding plates (Thermo Scientific) were coated with human IFN- $\gamma$ capture antibody (Thermo Fisher Scientific) in a binding buffer $\left(0 \cdot 1 \mathrm{M}-\mathrm{Na}_{2} \mathrm{HPO}_{4}\right)$ and incubated overnight at $+4^{\circ} \mathrm{C}$. Blocking was performed using $1 \%$ bovine serum albumin in PBS. The plates were washed with $0.05 \%$ Tween in PBS. IFN- $\gamma$ in undiluted culture supernatant samples was detected using biotinylated secondary IFN- $\boldsymbol{\gamma}$ antibody (Thermo Fisher Scientific) and biotin-specific streptavidin-alkaline phosphatase (Invitrogen) with $p$-nitrophenylphosphate (Sigma-Aldrich) for colour formation and intensity readings at $405 \mathrm{~nm}$. Recombinant human IFN- $\gamma$ (R\&D Systems) at different dilutions was used for constructing a standard curve for calculation of the concentration of secreted IFN- $\gamma$ in the samples. Secreted IL-17A in cellculture supernatants was detected using the Human IL-17 DuoSet ELISA Kit (catalogue no. DY317) according to the manufacturer's instructions (R\&D Systems). To prevent inter-assay variation, the supernatant samples from one experiment including different treatments were always analysed in the same assay, i.e. on the same ELISA plate. The detection limit was determined as the lowest standard dilution in the analysis $(0 \cdot 78 \mathrm{ng} / \mathrm{ml}$ for IFN- $\boldsymbol{\gamma}$ and $15.6 \mathrm{pg} / \mathrm{ml}$ for IL-17A).

\section{Quantitative RT-PCR}

Total RNA was extracted from pelleted and lysed cultured cells using the RNeasy Mini Kit (Qiagen) with on-column
DNase I treatment. High-Capacity cDNA Reverse Transcription Kit (Applied Biosystems) was used for reverse transcription. Real-time detection of target gene complementary DNA amplification was performed using TaqMan Gene Expression Assays (Applied Biosystems) for IFN- $\gamma$ (Hs00174143_m1) and StepOnePlus instrument (Applied Biosystems) for IL-17A (Hs00174383_m1). RN18S1 (Hs03928985_g1) was used as an endogenous reference gene to calculate comparative/ $\Delta$ cycle threshold $\left(\Delta C_{\mathrm{t}}\right)$ values for IFN- $\gamma$ complementary DNA and IL-17 complementary DNA amplification. The $\Delta C_{\mathrm{t}}$ values of target gene amplification were compared with those of an inhouse calibrator sample for relative values of gene expression.

\section{Flow cytometry}

The purity of enriched $\mathrm{T}_{\text {eff }}$ and $\mathrm{T}_{\text {reg }}$ was verified by staining with anti-human CD3-phycoerythrin, CD4-peridinin chlorophyll, CD8-fluorescein isothiocyanate, CD14-allophycocyanin and CD25-allophycocyanin (Becton Dickinson) and with appropriate IgG1 isotype control (Becton Dickinson) and incubating at room temperature for $20 \mathrm{~min}$. Intranuclear staining for FOXP3 was performed with anti-human FoxP3-Alexa 488 (BioLegend) and isotype control IgG1 (BioLegend) after fixation and permeabilisation using the FoxP3 Fix/Perm Kit (BioLegend). Stimulated cells were incubated with GolgiStop (BD Biosciences) for $4 \mathrm{~h}$ and stained with anti-human CD4 and anti-human TIM-3-allophycocyanin (eBioscience) before intracellular staining with anti-human IFN- $\boldsymbol{\gamma}$-fluorescein isothiocyanate (BD Pharmingen) and anti-human IL-17A-phycoerythrin (eBioscience), which was performed using the BD Cytofix/Cytoperm Fixation/ Permeabilization Kit (BD Biosciences). Gal-9 in stimulated $\mathrm{T}_{\mathrm{reg}}$ was stained intracellularly with human anti-Gal9 (BioLegend) and $\operatorname{IgG} 1 \kappa$ (BioLegend) for isotype control using the BD Cytofix/ Cytoperm Fixation/Permeabilization Kit (BD Biosciences). For analysis of fluorescence intensity, cells were collected and resuspended in $300 \mu \mathrm{l}$ of $0.5 \%$ bovine serum albumin in PBS and detected using a FACSCalibur flow cytometer and CellQuest Pro software (Becton Dickinson). Results were analysed using FlowJo 7.6 software (Tree Star, Inc.).

\section{Statistical analysis}

The normality of quantitative RT-PCR and ELISA data was tested, and the data were found to not follow Gaussian distribution. Statistical differences between multiple groups were calculated using the paired non-parametric Friedman test. Statistical differences between two data groups were analysed using the paired non-parametric Wilcoxon test. Data analysis was carried out using GraphPad Prism 6 software (GraphPad Software, Inc.). Statistical significance was set at $P<0.05$.

\section{Results}

\section{Human regulatory $T$ cells produce galectin-9 after stimulation}

The kinetics of Gal-9 expression in stimulated $\mathrm{T}_{\text {reg }}$ collected from two different individuals was studied to determine the 
optimal time to assess the effects of lactose on Gal-9-mediated suppression. Enriched $\mathrm{T}_{\text {reg }}$ were stimulated with anti-CD3 and anti-CD28 for $6 \mathrm{~d}$, and the gene expression of Gal-9 was analysed at $24 \mathrm{~h}$ intervals. The peak transcription of Gal-9 occurred after $6 \mathrm{~d}$ of polyclonal stimulation of $\mathrm{T}_{\text {reg }}$ (data not shown). Intracellular Gal-9 production was also detected in enriched human $\mathrm{T}_{\text {reg, }}$, i.e. $\mathrm{CD}^{+} \mathrm{CD} 25^{+} \mathrm{CD} 127^{-}$after stimulation with anti-CD3 and anti-CD28 for $6 \mathrm{~d}$ (Fig. 1).

\section{Lactose inhibits regulatory $T$-cell-mediated down- regulation of pro-inflammatory cytokine production}

To measure the effects of lactose on $\mathrm{T}_{\text {reg }}$-mediated downregulation of $\mathrm{T}_{\text {eff }}$ pro-inflammatory IFN- $\boldsymbol{\gamma}$ and IL-17 cytokine production, $\mathrm{T}_{\text {eff }}$ were cultured as such and in co-cultures with $\mathrm{T}_{\text {reg. }}$. In the presence of $\mathrm{T}_{\text {reg, }}$, there was a decrease in the levels of IFN- $\gamma$ and IL-17 secreted by $\mathrm{T}_{\text {eff }}$ from a median of 8.8 to $3.9 \mathrm{ng} / \mathrm{ml}$ for IFN- $\gamma$ (Fig. 2(a); $P=0.003$ ) and from 0.83 to $0.64 \mathrm{ng} / \mathrm{ml}$ for IL-17 (Fig. 2 (b); $P=0.04$ ). $\mathrm{T}_{\text {reg-mediated }}$ suppression was inhibited when lactose was added to the cell culture, which led to an elevation in the levels of secreted IFN- $\boldsymbol{\gamma}$ (Fig. 2(a); median 16.4 v. $3.9 \mathrm{ng} / \mathrm{ml}, P<0.0001$ ) and IL-17 (Fig. 2(b); median $0.74 \quad v .0 .64 \mathrm{ng} / \mathrm{ml}, \quad P=0.005$ ).
No inhibitory effect of $\mathrm{T}_{\text {reg }}$ could be observed on the transcription of $I F N-\gamma$ or $I L-17$ (Fig. 2(c) and (d)); however, there was an increase in the relative levels of $I F N-\gamma$ transcripts from a median of 484 to 1294 when lactose was added to the co-culture (Fig. 2(c); $P<0 \cdot 0001$ ). No changes were observed in the levels of IFN- $\gamma$ secreted by stimulated $\mathrm{T}_{\text {eff }}$ cultured with lactose when compared with those secreted by stimulated $\mathrm{T}_{\text {eff }}$ cultured without lactose (median IFN- $\gamma$ values for $\mathrm{T}_{\text {eff }}=38.2 \mathrm{ng} / \mathrm{ml}$, range $=14.86-62.6 \mathrm{ng} / \mathrm{ml}$, and for $\mathrm{T}_{\mathrm{eff}}+-$ lactose $=41.4 \mathrm{ng} / \mathrm{ml}$, range $=3 \cdot 1-64.5 \mathrm{ng} / \mathrm{ml}, n 7, P=0.69$ ).

No changes could be observed in the percentage or fluorescence intensity of IFN- $\gamma$-producing $\mathrm{CD} 4^{+} \mathrm{TIM}-3^{+}$cells when cultured with $\mathrm{T}_{\text {reg }}$ with or without lactose ( $n$ 10). However, in three of the nine blood donors, lactose, but not sucrose, increased the percentage of IL-17-producing $\mathrm{CD} 4^{+}{ }^{\mathrm{TIM}}-3^{+}$cells and the intensity of IL- 17 in $\mathrm{CD} 4^{+} \mathrm{TIM}-3^{+}$ cells (data of one representative individual shown in Fig. 3).

\section{Discussion}

Our interest in dietary lactose as an immunomodulatory molecule results from studies showing that the Tim-3/Gal-9 pathway is crucial for regulating $\mathrm{T}$-cell responses both (a)

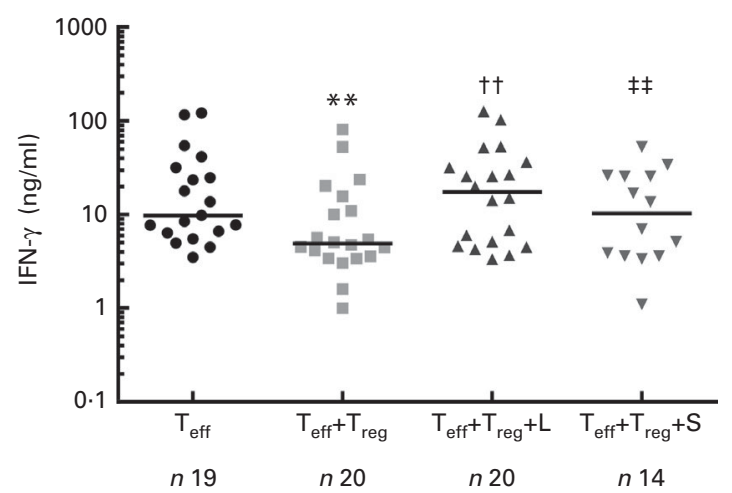

(c)

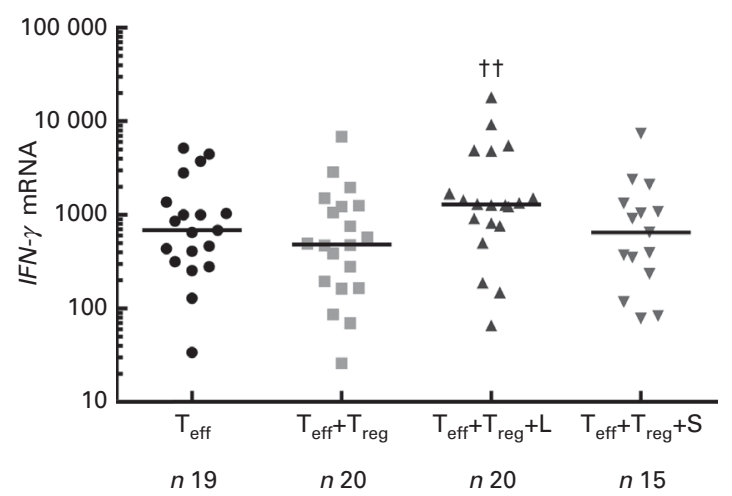

(b)

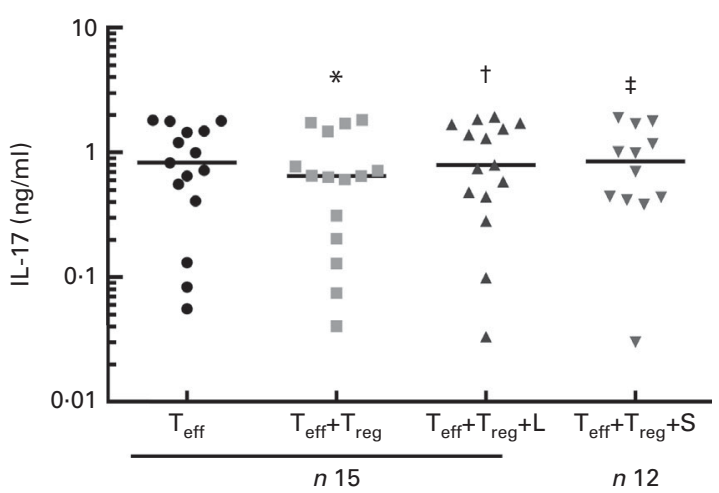

(d)

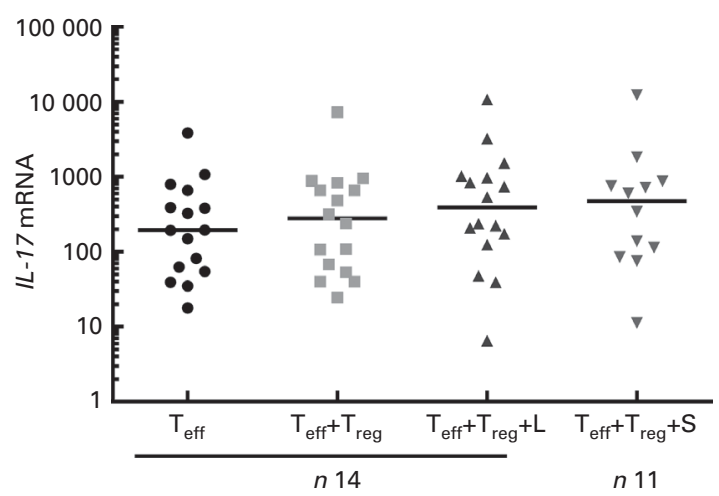

Fig. 2. Modulation of the functions of effector $T$ cells $\left(T_{\text {eff }}\right)$ by regulatory $T$ cells $\left(T_{\text {reg }}\right)$ and lactose $(L)$ in healthy study subjects. $T_{\text {eff }}$ were cultured as such and in

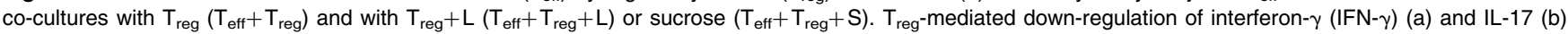
secretion was inhibited by lactose. Lactose increased the transcription of $I F N-\gamma$ (c), but not of $I L-17$ (d), in $T_{\text {eff }}$ co-cultured with $\mathrm{T}_{\text {reg. }}$. Data are represented as minimum to maximum with the median represented by a horizontal line. Cytokine levels in cell-culture supernatants were assessed with ELISA and relative gene expression of the cells was assessed with quantitative RT-PCR. $P$ values were calculated using the Wilcoxon signed-rank test for paired samples. Median value was significantly different from that obtained for $\mathrm{T}_{\text {eff }}:{ }^{*} P=0.04 ;{ }^{*} P=0.003$. Median value was significantly different from that obtained for $\mathrm{T}_{\text {eff }}+\mathrm{T}_{\text {reg: }} \dagger P=0.005$; $\dagger \dagger P<0.0001$. Median value was significantly different from that obtained for $\mathrm{T}_{\text {eff }}+\mathrm{T}_{\text {reg }}+\mathrm{L}: \ddagger P=0.01 ; \ddagger \ddagger P=0.0002$. 
(a)
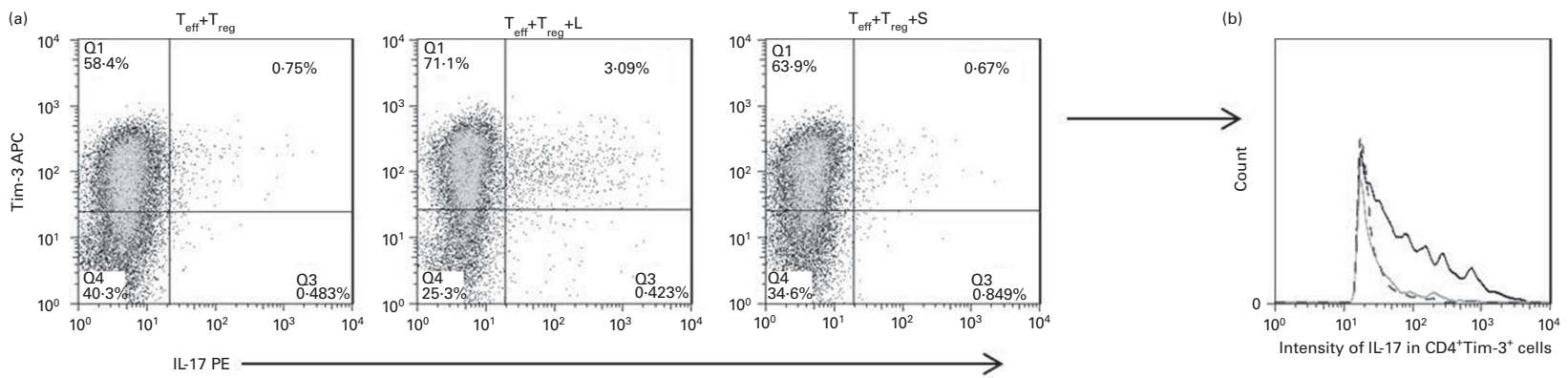
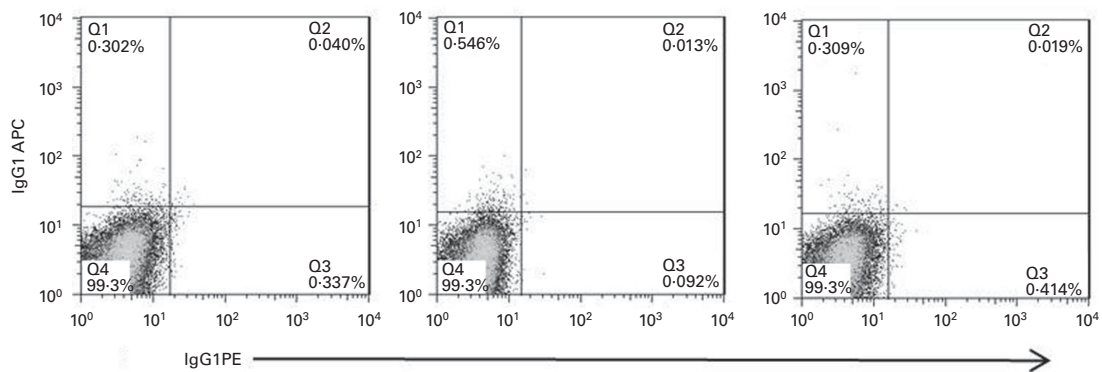

Fig. 3. Response exhibited by some individuals to lactose (L) through up-regulation of IL-17 production in $\mathrm{CD} 4^{+} \mathrm{TIM}-3^{+}$cells. The percentage (a) and fluorescence intensity (b) of IL-17 in $\mathrm{CD} 4^{+} \mathrm{TIM}-3^{+}$cells were increased in the presence of lactose; data for a representative case of one individual in whom lactose induced an increase in the IL-17 response of $\mathrm{CD}_{4}{ }^{+} \mathrm{TIM} 3^{+}$cells. $\mathrm{T}_{\text {eff, }}$ effector $\mathrm{T}$ cells; $\mathrm{T}_{\text {reg, }}$, regulatory $\mathrm{T}$ cells; $\mathrm{S}$, sucrose; TIM-3, T-cell Ig and mucin domain-3; APC, allophycocyanin; PE, phycoerythrin. ...., $\mathrm{T}_{\text {eff }}+\mathrm{T}_{\text {reg }} ; \ldots, \mathrm{T}_{\text {eff }}+\mathrm{T}_{\text {reg }}+\mathrm{L} ;-, \mathrm{T}_{\text {eff }}+\mathrm{T}_{\text {reg }}+\mathrm{S}$.

in vitro and in vivo and can be blocked with lactose. In the present study, we showed in a remarkable number of healthy

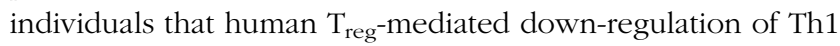
and Th17 immune responses is specifically inhibited by lactose, as evidenced by an increased expression of IFN- $\gamma$ and IL-17 in vitro. The suppressive effect of $\mathrm{T}_{\text {reg }}$ on IFN- $\gamma$ expression at both the transcriptional and protein levels was blocked by lactose, which emphasises the importance of Gal-9 as a mediator of immune regulation expressed by $\mathrm{T}_{\text {reg }}$ and the role of lactose as a potent immunomodulator. When $\mathrm{T}_{\text {eff }}$ were stimulated with lactose, no changes were observed in the secretion of IFN- $\gamma$. This indicates that the effects of lactose were mediated by the inhibition of $\mathrm{T}_{\text {reg }}$-mediated suppression and not by direct effects on $\mathrm{T}_{\text {eff }}$. We also provide preliminary evidence that lactose may increase IL-17 responses in $\mathrm{CD}_{4}{ }^{+} \mathrm{TIM}-3^{+}$cells in some individuals. The results of the present study are in agreement with a recent report showing that human $\mathrm{T}_{\text {reg }}$ express Gal-9 and that lactose can block Gal-9-mediated suppression of HIV-specific $\mathrm{CD}^{+}$ cells in humans ${ }^{(26)}$. In addition, it has been demonstrated that human T-cell-derived Gal-9 is a regulator of $\mathrm{Th} 17 / \mathrm{T}_{\text {reg }}$ development ${ }^{(27)}$.

Human breast milk, containing $7 \%$ lactose, provides infants with nutrients and immunoprotection, in the form of maternal antibodies, antimicrobial peptides, immune cells and cytokines ${ }^{(28,29)}$. Neonates are exposed to enormous amounts of new microbes, non-pathogens and pathogens and are particularly susceptible to infection. The adaptive immune system of a neonate is immature and Th2-biased and the neonatal immunity relies strongly on innate immunity mechanisms ${ }^{(30,31)}$. Cederlund et $a l .{ }^{(32)}$ are the first to show that breast milk lactose exhibits immunomodulatory properties by inducing the transcription of the cathelicidin antimicrobial peptide (CAMP), gene encoding the antimicrobial protein LL-37 in colonic epithelial cells and in cells of the innate immune system. We propose that breast milk lactose could have beneficial effects on immunity during infancy by indirectly enhancing the IFN- $\gamma$ and IL-17 responses of $\mathrm{T}_{\text {eff. Breast milk lactose }}$ could thus be an important mediator of immunoprotection against mucosal pathogens, as shown in an animal model by Sehrawat et $a l .{ }^{(16)}$. It has been demonstrated that disaccharides such as lactulose, which is used for the assessment of smallintestinal permeability, cross the intestinal barrier in infants and also in individuals with increased intestinal permeability ${ }^{(33)}$. In addition, milk oligosaccharides from dietary sources have been shown to interact with cells of the innate immune system in the lamina propria and to promote intestinal inflammation through interaction of sialyl $(\alpha 2,3)$ lactose and Toll-like receptor 4 in a mouse model of colitis ${ }^{(34)}$. This provides evidence that food-derived oligosaccharides might play a role in the regulation of mucosal immunity in the intestine.

Given that oligosaccharides reach lamina propria, it is plausible that in individuals susceptible to chronic inflammatory diseases, dietary lactose could induce harmful inflammatory responses by disrupting $\mathrm{T}_{\text {reg-mediated regulation as shown }}$ in the present study. The incidence of autoimmune diseases, chronic inflammatory disorders and allergy has increased during the last few decades, especially in Western societies, and cannot be explained by changes in genetic predisposition. Versatile environmental factors are thought to play a key role in these immune-mediated disorders as reviewed by Mohan $^{(35)}$ and Smyk et al. ${ }^{(36)}$. Uncontrolled Th1 and Th17 immune responses and the inability of $\mathrm{T}_{\text {reg }}$ to down-regulate immune responses have been implicated in the pathogenesis of many human immune-mediated diseases ${ }^{(37)}$. Moreover, Gal-9 has been shown to inhibit IgE-antigen complex for- 
mation and mast cell degranulation and alleviate allergic status in mice. The anti-allergic effect of Gal-9 has been found to be completely inhibited by lactose ${ }^{(12)}$. As mast cells are also located in the intestinal lamina propria with implications in gastrointestinal disease ${ }^{(38)}$, the role of dietary lactose in the exacerbation of allergic inflammation in individuals with food allergy should be considered. In populations with a high proportion of lactose-tolerant individuals, due to the high frequency of lactase gene mutation contributing to the persistent intestinal lactase production during adulthood, lactose intake from the diet is relatively eminent ${ }^{(4,39,40)}$. Interestingly, the incidence of some immune-mediated diseases is high among these populations ${ }^{(41-43)}$. It is also possible that the intestinal problems associated with genetic lactose intolerance may not always be caused by lactose-related osmotic changes, but could be of immunological origin.

Taken together, lactose has strong immune-modulating properties, which we have demonstrated in the present study in vitro in human subjects and which have been shown earlier both in vitro and in vivo in mice. Physiological relevance of our preliminary results and effects of dietary lactose on the human gut immune system and health need to be studied further.

\section{Acknowledgements}

The authors thank Anneli Suomela for helping with quantitative RT-PCR analysis and study nurse Anne Nikkonen for helping with sample collection.

The present study was supported by Semper Limited (M. P.) and Sigrid Jusélius Foundation, Pediatric Research Foundation and Helsinki University Hospital Research Fund (K.-L. K.). The study sponsors had no role in the study design; collection, analysis, and interpretation of the data; writing of the article; or decision to submit the article for publication.

The authors' contributions are as follows: M. P. and J. H. were responsible for the immunological experiments and data analysis; M. P., J. H. and O. V. were responsible for the study design; K.-L. K. recruited the study subjects; M. P. wrote the first draft of the manuscript; J. H., O. V. and K.-L. K. contributed to the critical revision of the manuscript.

None of the authors has any conflicts of interest to declare.

\section{References}

1. Francavilla R, Calasso M, Calace L, et al. (2012) Effect of lactose on gut microbiota and metabolome of infants with cow's milk allergy. Pediatr Allergy Immunol 23, 420-427.

2. Rasinpera H, Kuokkanen M, Kolho KL, et al. (2005) Transcriptional downregulation of the lactase (LCT) gene during childhood. Gut 54, 1660-1661.

3. Sahi T (1994) Hypolactasia and lactase persistence. Historical review and the terminology. Scand J Gastroenterol Suppl 202, $1-6$.

4. Enattah NS, Sahi T, Savilahti E, et al. (2002) Identification of a variant associated with adult-type hypolactasia. Nat Genet 30, 233-237.

5. Tureci O, Schmitt H, Fadle N, et al. (1997) Molecular definition of a novel human galectin which is immunogenic in patients with Hodgkin's disease. J Biol Chem 272, 6416-6422.

6. Wada J \& Kanwar YS (1997) Identification and characterization of galectin-9, a novel $\beta$-galactoside-binding mammalian lectin. J Biol Chem 272, 6078-6086.

7. Chen X, Song CH, Liu ZQ, et al. (2011) Intestinal epithelial cells express galectin-9 in patients with food allergy that plays a critical role in sustaining allergic status in mouse intestine. Allergy 66, 1038-1046.

8. Jayaraman P, Sada-Ovalle I, Beladi S, et al. (2010) Tim3 binding to galectin-9 stimulates antimicrobial immunity. $J$ Exp Med 207, 2343-2354.

9. Matsumoto R, Matsumoto H, Seki M, et al. (1998) Human ecalectin, a variant of human galectin-9, is a novel eosinophil chemoattractant produced by T lymphocytes. $\mathrm{J}$ Biol Chem 273, 16976-16984.

10. Hirashima M, Kashio Y, Nishi N, et al. (2004) Galectin-9 in physiological and pathological conditions. Glycoconj J 19, 593-600.

11. Kashio Y, Nakamura K, Abedin MJ, et al. (2003) Galectin-9 induces apoptosis through the calcium-calpain-caspase-1 pathway. J Immunol 170, 3631-3636.

12. Niki T, Tsutsui S, Hirose S, et al. (2009) Galectin-9 is a high affinity IgE-binding lectin with anti-allergic effect by blocking IgE-antigen complex formation. J Biol Chem 284, $32344-32352$.

13. Seki M, Oomizu S, Sakata KM, et al. (2008) Galectin-9 suppresses the generation of Th17, promotes the induction of regulatory $\mathrm{T}$ cells, and regulates experimental autoimmune arthritis. Clin Immunol 127, 78-88.

14. Bi S, Hong PW, Lee B, et al. (2011) Galectin-9 binding to cell surface protein disulfide isomerase regulates the redox environment to enhance T-cell migration and HIV entry. Proc Natl Acad Sci US A 108, 10650-10655.

15. Zhu C, Anderson AC, Schubart A, et al. (2005) The Tim-3 ligand galectin-9 negatively regulates $\mathrm{T}$ helper type $1 \mathrm{immu}-$ nity. Nat Immunol 6, 1245-1252.

16. Sehrawat S, Reddy PB, Rajasagi N, et al. (2010) Galectin-9/ TIM-3 interaction regulates virus-specific primary and memory CD8 T cell response. PLoS Pathog 6, e1000882.

17. Hastings WD, Anderson DE, Kassam N, et al. (2009) TIM-3 is expressed on activated human $\mathrm{CD}^{+} \mathrm{T}$ cells and regulates Th1 and Th17 cytokines. Eur J Immunol 39, 2492-2501.

18. Chabot S, Kashio Y, Seki M, et al. (2002) Regulation of galectin-9 expression and release in Jurkat T cell line cells. Glycobiology 12, 111-118.

19. Oomizu S, Arikawa T, Niki T, et al. (2012) Galectin-9 suppresses Th17 cell development in an IL-2-dependent but Tim-3-independent manner. Clin Immunol 143, 51-58.

20. Damsker JM, Hansen AM \& Caspi RR (2010) Th1 and Th17 cells: adversaries and collaborators. Ann $N$ Y Acad Sci 1183, 211-221.

21. Sakaguchi S (2005) Naturally arising Foxp3-expressing $\mathrm{CD} 25^{+} \mathrm{CD} 4^{+}$regulatory $\mathrm{T}$ cells in immunological tolerance to self and non-self. Nat Immunol 6, 345-352.

22. Sakaguchi S, Sakaguchi N, Asano M, et al. (1995) Immunologic self-tolerance maintained by activated $\mathrm{T}$ cells expressing IL-2 receptor $\alpha$-chains (CD25). Breakdown of a single mechanism of self-tolerance causes various autoimmune diseases. J Immunol 155, 1151-1164.

23. Shimizu J, Yamazaki S, Takahashi T, et al. (2002) Stimulation of $\mathrm{CD} 25^{+} \mathrm{CD}^{+}$regulatory $\mathrm{T}$ cells through GITR breaks immunological self-tolerance. Nat Immunol 3, 135-142.

24. Dunham RM, Cervasi B, Brenchley JM, et al. (2008) CD127 and $\mathrm{CD} 25$ expression defines $\mathrm{CD}^{+}{ }^{+} \mathrm{T}$ cell subsets that are 
differentially depleted during HIV infection. J Immunol 180, 5582-5592.

25. Seddiki N, Santner-Nanan B, Martinson J, et al. (2006) Expression of interleukin (IL)-2 and IL-7 receptors discriminates between human regulatory and activated $\mathrm{T}$ cells. J Exp Med 203, 1693-1700.

26. Elahi S, Dinges WL, Lejarcegui N, et al. (2011) Protective HIV-specific $\mathrm{CD}^{+} \mathrm{T}$ cells evade $\mathrm{T}_{\text {reg }}$ cell suppression. Nat Med 17, 989-995.

27. Oomizu S, Arikawa T, Niki T, et al. (2012) Cell surface galectin-9 expressing Th cells regulate Th17 and Fox ${ }^{+} \mathrm{T}_{\text {reg }}$ development by galectin-9 secretion. PLOS ONE 7, e48574.

28. Hosea Blewett HJ, Cicalo MC, Holland CD, et al. (2008) The immunological components of human milk. Adv Food Nutr Res 54, 45-80.

29. Wagner CL, Taylor SN \& Johnson D (2008) Host factors in amniotic fluid and breast milk that contribute to gut maturation. Clin Rev Allergy Immunol 34, 191-204.

30. Adkins B, Leclerc C \& Marshall-Clarke S (2004) Neonatal adaptive immunity comes of age. Nat Rev Immunol 4, $553-564$.

31. Stockinger S, Hornef MW \& Chassin C (2011) Establishment of intestinal homeostasis during the neonatal period. Cell Mol Life Sci 68, 3699-3712.

32. Cederlund A, Kai-Larsen Y, Printz G, et al. (2013) Lactose in human breast milk an inducer of innate immunity with implications for a role in intestinal homeostasis. PLOS ONE 8, e53876.

33. Mishra A \& Makharia GK (2012) Techniques of functional and motility test: how to perform and interpret intestinal permeability. J Neurogastroenterol Motil 18, 443-447.
34. Kurakevich E, Hennet T, Hausmann M, et al. (2013) Milk oligosaccharide sialyl $(\alpha 2,3)$ lactose activates intestinal CD11c ${ }^{+}$cells through TLR4. Proc Natl Acad Sci U S A 110, $17444-17449$.

35. Mohan C (2006) Environment versus genetics in autoimmunity: a geneticist's perspective. Lupus 15, 791-793.

36. Smyk D, Rigopoulou EI, Baum H, et al. (2012) Autoimmunity and environment: am I at risk? Clin Rev Allergy Immunol $\mathbf{4 2}$, 199-212.

37. Weaver CT, Elson CO, Fouser LA, et al. (2013) The Th17 pathway and inflammatory diseases of the intestines, lungs, and skin. Annu Rev Pathol 8, 477-512.

38. Ramsay DB, Stephen S, Borum M, et al. (2010) Mast cells in gastrointestinal disease. Gastroenterol Hepatol (N Y) 6 , $772-777$.

39. Flatz G \& Rotthauwe HW (1977) The human lactase polymorphism: physiology and genetics of lactose absorption and malabsorption. Prog Med Genet 2, 205-249.

40. Smith GD, Lawlor DA, Timpson NJ, et al. (2009) Lactase persistence-related genetic variant: population substructure and health outcomes. Eur J Hum Genet 17, 357-367.

41. Compston A \& Coles A (2008) Multiple sclerosis. Lancet 372 , 1502-1517.

42. Maahs DM, West NA, Lawrence JM, et al. (2010) Epidemiology of type 1 diabetes. Endocrinol Metab Clin North Am 39, 481-497.

43. Molodecky NA, Soon IS, Rabi DM, et al. (2012) Increasing incidence and prevalence of the inflammatory bowel diseases with time, based on systematic review. Gastroenterology 142, 46-54. 